\title{
ANALISIS FLUKTUASI DAN ELASTISITAS TRANSMISI HARGA KENTANG DI KABUPATEN MAGELANG
}

\author{
ANALYZE OF PRICE FLUCTUATION AND PRICE TRANSMISSION ELASTICITY OF \\ POTATO IN MAGELANG REGENCY
}

\author{
Nun Maulida Suci Ayomi, Bambang M. Setiawan., dan Wiludjeng Roessali \\ Program Studi Magister Agribisnis Fakultas Peternakan dan Pertanian \\ Universitas Diponegoro \\ Email: suciayomi@gmail.com \\ Diterima: 8 Nopember 2020, Direvisi: 24 Nopember 2020, Disetujui: 2 Desember 2020
}

\begin{abstract}
ABSTRAK
Selisih harga atau perbedaan harga yang diterima oleh petani dengan harga yang harus dibayarkan oleh konsumen, menunjukkan bahwa harga yang dibayarkan oleh konsumen bukanlah harga yang diterima oleh petani. Penelitian ini bertujuan untuk menganalisis fluktuasi harga dan elastisitas transmisi harga kentang di Kabupaten Magelang. Penelitian menggunakan data sekunder selama 156 minggu dari tahun 2016 - 2018. Analisis yang digunakan untuk mengetahui fluktuasi harga dengan koefisien keragaman, dan untuk mengetahui elastisitas transmisi harga adalah regesi liner sederhana. Hasil penelitian menunjukkan bahwa nilai koefisien keragaman sebesar 15,70\% sehingga fluktuasi harga kentang ditingkat pedagang pengecer cukup tinggi, dan nilai elastisitas transmisi harga kentang di Kabupaten Magelang inelastic $(<1)$, sehingga laju perubahan ditingkat petani lebih kecil dibanding dengan perubahan harga ditingkat pedagang. Penurunan produksi membuat dampak dari adanya harga kentang yang tidak pasti dari musim ke musim. Rantai pemasaran yang panjang mempengaruhi elastisitas transmisi harga. Petani yang bertindak sebagai penerima harga, hanya dapat menerima harga yang sudah diberikan oleh pedagang pengumpul desa.
\end{abstract}

Kata kunci: fluktusi harga, transmisi harga, kentang

\begin{abstract}
The price difference was received by farmers and the price was paid by consumers indicates that the price paid by consumers is not the price received by farmers. This study aims to analyze the price fluctuation and elasticity of price transmission potato in Magelang Regency. This research have secondary data during 156 weeks on 2016 until 2018. An instrument analyze used coefficient of variation for price fluctuation and simple linier regression for elasticity of price transmission. The results of research revealed that value coefficient of variation 15,70\% this mean price fluctuation potato in Magelang Regency was high, and elasticity of price transmission potato was small $(\eta=0,950)$ is inelastic $(E<1)$ which means the sensitivity of price changes at the farm level is smaller than the price change at the merchant level. Decreasing potato in production was resulted in impact of the price of potato which was uncertain from season to another season. The long marketing chain affects elasticity of price transmission. Farmers who act as price taker, only received the price that has been given by the village collectors.
\end{abstract}

Key words: price fluctuation, price transmission, potato. 


\section{PENDAHULUAN}

Kentang merupakan salah satu pangan utama dunia setelah padi, gandum, dan jagung. Kentang termasuk kedalam tanaman hortilkutura yang dibudidayakan dan dikembangan oleh masyarakat luas untuk pemenuhan kebutuhan. Kentang merupakan salah satu komoditas hortikultura yang dapat menggantikan beras, dikarenakan umbi kentang memiliki karbohidrat, vitamin, dan mineral yang cukup tinggi. (Handayani et al., 2013).

Konsumsi kentang rumah tangga di Provinsi Jaw Tengah rata-rata 6,43 $\mathrm{kg} / \mathrm{kapita} /$ tahun. Jawa Tengah merupakan peringkat ketiga terbesar di Indonesia dengan produksi kentang pada tahun 2018 yaitu sebesar $7,48 \%$ dengan luas lahan yang dimiliki sebesar 10.171 hektar, disusul Provinsi Jawa Barat dan Sumatera Utara dengan masing-masing menyumbang sebesar 35,26\%, dan 10,78\% (Direktorat Jenderal Hortikultura, 2018). Kabupaten Magelang merupakan sentra penghasil kentang di Jawa Tengah dengan total produksi 79.836 ton (Direktorat Jenderal Hortikultura, 2018). Produksi kentang di Kabupaten Magelang selama tiga tahun terkahir mengalami fluktuatif, pada tahun 2016 produksi yang dihasilkan sebesar 10.478 ton, tahun 2017 meningkat menjadi 13.400 ton, dan tahun 2018 produksi menurun menjadi 6.031 ton (BPS Kabupaten Magelang, 2018).

Harga kentang di Kabupaten Magelang tertinggi pada tahun 2018 ditingkat produsen sebesar Rp. 11.000 per kilogram dan harga terendah sebesar Rp.7.400 per kilogram. Harga kentang pada tingkat pedagang pengecer tertinggi sebesar Rp.17.500 per kilogram, sedangkan untuk harga terendah sebesar Rp. 10.800 per kilogram (Pusdatin
Kementerian Pertanian, 2018). Selisih harga atau perbedaan harga yang diterima oleh petani dengan harga yang harus dibayarkan oleh konsumen, menunjukkan bahwa harga yang dibayarkan oleh konsumen bukanlah harga yang diterima oleh petani.

Pada tahun 2016 menurut penelitian Purwanto., et al. (2016) biaya untuk budidaya kentang di Kabupaten Magelang rata-rata sebesar Rp. 11.413.217,00 selama satu kali masa tanam (4 bulan) dengan keuntungan yang diterima oleh petani sebesar Rp. 4.827.017,00. Fatimah (2011) mengatakan bahwa rantai pemasaran kentang di Kabupaten Magelang cukup panjang, meliputi petani - pedagang pengumpul desa- pedagang besar - konsumen. Tinggi rendahnya harga yang diterima konsumen dipengaruhi oleh biaya produksi, serta rantai pemasaran kentang yang panjang. Melalui mekanisme harga dalam sistem pemasaran pada permintaan konsumen dapat mengakibatkan terjadinya keuntungan maupun kerugian (Asmarantaka, 2012).

Rantai pemasaran yang panjang serta adanya market power yang dimiliki pedagang pengumpul desa atau pedagang perantara merupakan faktor yang mempengaruhi disparitas harga. Tahun 2011 nilai marjin pemasaran kentang di Kabupaten Magelang sebesar Rp. 919,15 per kilogram. Pedagang pengumpul desa sebagai perantara pertama memperoleh nisbah marjin keuntungan sebesar 3,92\%, sedangkan pedagang besar sebesar 2,25\% (Fatimah, 2011). Tingginya marjin pemasaran dan transmisi harga dipengaruhi oleh market power yang dimiliki pedagang pengumpul desa atau pedagang perantara sehingga menunjukkan bahwa pasar yang dihadapi merupakan pasar yang terkonsen- 
trasi, sehingga power yang dimiliki oleh pedagang perantara dalam menetapkan harga semata hanya untuk keuntungan yang maksimal bagi pedagang. Penelitian ini bertujuan untuk mengkaji elastisitas transimis harga kentang dan fluktuasi harga kentang di Kabupaten Magelang.

\section{METODE PENELITIAN}

Penelitian ini menggunakan data sekunder yang diperoleh dari Pusat Data dan Informasi Harga Hortikultura Kementrian Pertanian. Harga kentang menjadi aspek dalam obyek penelitian. Jenis data yang digunakan dalam penelitian ini adalah data sekunder. Data yang digunakan adalah harga kentang ditingkat petani (produsen) di Kabupaten Magelang dan harga kentang ditingkat pedagang pengecer di Kabupaten Magelang selama 156 minggu (3 tahun) pada tahun 2016 sampai dengan tahun 2018. Data runtut waktu (time series) adalah nilai-nilai suatu variabel yang berurutan menurut waktu.

Analisis fluktuasi harga menggunakan Coefficient of Variation atau koefisien keragaman (KK) harga, dimana merupakan rasio antara simpangan standar (standard deviation) dengan nilai rata-rata (mean) dan dinyatakan dalam persentase yang berguna untuk melihat sebaran data dari rata-rata hitungnya (Walpole, 2000). Rumus keofisien keragaman sebagai berikut:

$$
\mathrm{KK}=\underline{\alpha} \times 100 \%
$$

Dimana $\alpha$ adalah standar deviasi dan $\mu$ adalah rata-rata harga kentang ditingkat pedagang pengecer. Koefisien variasi harga kentang pada pasar konsumen berkisar antara 14,54\% hingga 33,85\% (Irawan, 2017).
Nilai elastisitas transmisi harga dianalisis dengan cara regresi linier sederhana, persamaan hubungan antara harga ditingkat produsen (Pf) dan harga ditingkat pengecer (Pr). Secara matematis elastisitas transmisi harga (Et) dapat dituliskan sebagai :

$\mathrm{Pf}=\mathrm{b} 0+\mathrm{b} 1 \mathrm{Pr}$

Ditransformasikan dalam bentuk logaritma natural menjadi:

Ln Pf $=$ Ln b0 + b1 ln Pr

Dimana:

b0 = intersep

b1 = Koefisien elastisitas transmisi harga

Pf = Harga ditingkat pedagang

$\operatorname{Pr}=$ Harga ditingkat petani

Kriteria pengukuran analisis elastisitas transmisi harga apabila nilai $\mathrm{Et}=1$ menunjukkan laju perubahan harga ditingkat petani sama dengan laju perubahan harga di tingkat pedagang. Nilai Et <1 menunjukkan laju perubahan harga ditingkat pedagang pengecer lebih kecil dibandingkan dengan laju perubahan harga di tingkat petani. Nilai Et $>1$, maka laju perubahan harga ditingkat petani lebih besar dibandingkan dengan laju perubahan harga ditingkat pedagang pengecer (Kusumah, 2018).

\section{HASIL DAN PEMBAHASAN}

\section{Analisis Fluktuasi Harga}

Perkembangan harga kentang di Kabupaten Magelang pada tahun 2016 rata-rata harga kentang Rp. 11.552,00 per kilogram, dengan harga minimum Rp. 7.500,00 per kilogram terjadi pada minggu ketiga dan keempat bulan Maret (minggu ke 11 dan 12), dan harga maksimum Rp. $17.333,00$ per kilogram terjadi pada minggu kedua bulan Juli (minggu ke 28). Rata-rata harga kentang tahun 2017 sebesar Rp. 12.837,33 per koligram. Harga minimum kentang tahun 2017 sebesar Rp. 
$11.000,00$ per kilogram terjadi pada bulan Maret minggu ketiga sampai dengan bulan April minggu ketiga (minggu ke 63 sampai dengan minggu ke 68), dan untuk harga maksimum terjadi pada bulan Juni minggu kelima dengan harga Rp. 16.500,00 per kilogram (minggu ke 78). Tahun 2018 memiliki rata-rata harga kentang sebesar Rp. 11.457,69 per koligram, dengan harga minimum sebesar Rp. 10.000,00 per koligram terjadi pada bulan Juli minggu pertama (minggu ke 131), dan pada minggu kedua pada bulan Januari terjadi harga maksimum sebesar Rp. 14.700,00 per klogram (minggu ke 106).

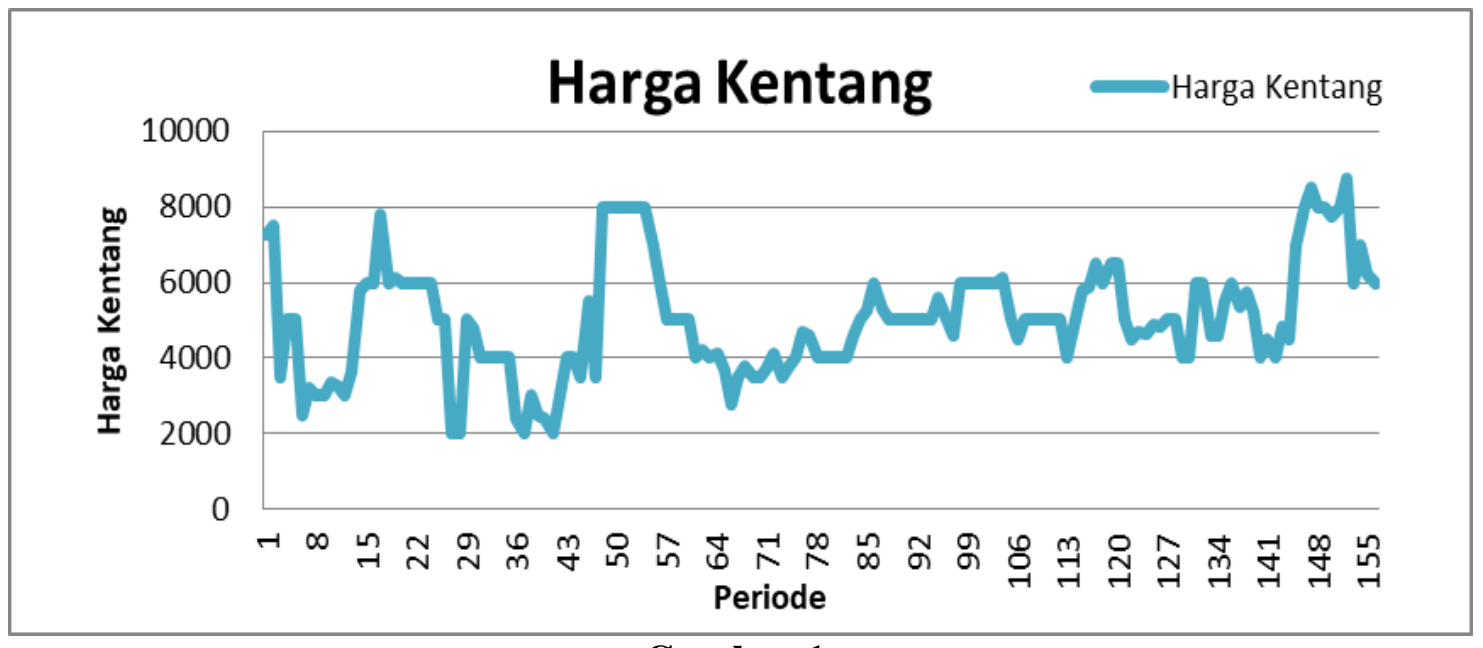

\section{Gambar 1.}

Grafik Fluktuasi Harga Kentang Ditingkat Pedagang Pengecer.

Sumber: Pusat Data dan Informasi Harga Hortikultura Kementerian Pertanian 2016 - 2018.

Besarnya tingkat fluktuasi harga kentang dapat ditunjukkan dengan perkembangan nilai koefisien keragaman. Nilai koefisien keragaman harga kentang sebesar $15,70 \%$ dibandingkan dengan penelitian Andriani (2017) nilai koefisien keragaman kentang sebesar $22,71 \%$. Nilai yang didapat lebih kecil apabila dibandingkan dengan penelitian sebelumnya. Menurut Irawan (2017) pada pasar konsumen koefisien variasi harga kentang berkisar antara 14,54\% hingga 33,85\%.

Pertumbuhan harga kentang nasional dari tahun 2016 sampai dengan 2018 mengalami fluktuatif, rata-rata harga kentang ditingkat pedagang pengecer tahun 2016 sebesar Rp. 10.467,00 per kilogram, tahun 2017 rata-rata harga kentang naik menjadi Rp. $18.467,00$ per kilogram; dan pada tahun 2018 rata-rata harga kentang turun menjadi Rp. 16.200,00 per kilogram (Pusdatin Kementerian Pertanian, 2018). Perbandingan harga kentang ditingkat Kabupaten Magelang lebih rendah dibandingkan dengan harga kentang di tingkat nasional. Produksi kentang di Kabupaten Magelang dari tahun 2016 sampai dengan tahun 2018 selalu mengalami penurunan. Tahun 2016 produksi yang dihasilkan sebesar 81.645 ton, tahun 2017 sebanyak 72.461 ton, dan tahun 2018 produksi menurun menjadi 57.546 ton (BPS Kabupaten Magelang, 2018). Penurunan produksi membuat dampak dari adanya harga kentang yang tidak pasti dari musim ke musim. Ketidakseimbangan antara kuantitas pasokan kentang dan kuantitas permintaan 
konsumen pada kentang membuat adanya fluktuasi harga. Menuurt Pagala (2017) akibat dari ketidakstabilan (inherentinstability) pada sisi penawaran produk pertanian menjadi fenomena yang umum terjadinya fluktuasi harga di sektor pertanian. Harga pada hasil pertanian disebabkan oleh produksi pertanian itu sendiri, tidak dapat merespon penambahan permintaan dalam jangka pendek atau pada saat harga rendah produksi tidak dapat dikurangi. Salah satu faktor yang mempengaruhi permintaan adalah perkiraan harga di masa mendatang. Fluktuasi harga yang terjadi pada produk hortikultura erat kaitannya dengan sifat dari produk itu sendiri yang memiliki umur simpan relatif singkat atau tidak dapat disimpan dalam waktu yang lama. Iklim juga mempengaruhi fluktuasi harga, dimana pada saat musim penghujan sangat berpotensi menghadapi kegagalan panen.

Setiawan dan Adi (2014) berpendapat bahwa fluktuasi harga seringkali merugikan petani sebagai produsen daripada pedagang pengumpul, situasi ini terjadi karena petani tidak dapat menentukan kapan harus melakukan penjualan agar mendapatkan harga yang maksimal, hal ini terjadi karena sifat produk hortikultura yang mudah rusak dan memiliki umur simpan yang singkat.

\section{Analisis Elastisitas Transmisi Harga}

Analisis elastisitas transmisi harga adalah analisis yang menggambarkan sejauh mana dampak perubahan harga suatu barang di satu tempat atau tingkatan terhadap perubahan harga barang itu di tempat atau tingkatan lain.

Tabel 1.

Hasil Analisis Elastisitas Transmisi Harga Kentang

\begin{tabular}{lccccc}
\hline \hline & B & Std. Error & Beta & T & Sig. \\
\hline Pf & 0,950 & 0,022 & 0,960 & 42,291 & 0,000 \\
Constant & 0,264 & 0,211 & & 1,254 & 0,212 \\
\hline
\end{tabular}

Hasil analisis menunjukkan bahwa elstisitas transmisi harga kentang inelastik karena $\mathrm{E}<1(0,950)$ dengan demikian laju perubahan harga kentang ditingkat pedagang pengecer lebih besar dari laju perubahan harga kentang ditingkat petani atau produsen. Apabila terjadi perubahan harga di pedagang pengecer $1 \%$ maka perubahan harga ditingkat petani $0,950 \%$ dalam kondisi satu arah. Martin (2002) menyatakan apabila pada tingkat konsumen mengalami kenaikan harga maka pedagang dapat meneruskan kenaikan harga yang dialami pada tingkat konsumen kepada petani secara tidak sempurna, dengan kata lain petani lebih rendah menerima kenaikan harga dibandingkan dengan kenaikan harga yang dibayar konsumen. Transmisi harga yang seperti ini tidak menguntungkan petani selaku produsen karena adanya kenaikan harga yang terjadi ditingkat konsumen tidak dapat dinikmati oleh petani dalam memperoleh keuntungan usahataninya, sebaliknya apabila terjadi penurunan harga maka pedagang baik pedagang pengepul maupun pedagang besar akan memberikan informasi langsung kepada petani saat itu juga. Rahayu (2009) menambahkan apabila nilai elastisitas transmisi harga kurang dari satu $(\mathrm{Et}<1)$ maka disebut inelastik, dimana laju perubahan harga ditingkat pedagang pengecer lebih besar jika dibandingkan dengan laju perubahan 
ditingkat produsen (petani). Menurut Irawan (2017) transmisi harga yang rendah mencerminkan pemasaran yang inefisien dimana perubahan harga yang terjadi di tingkat konsumen tidak seluruhnya diteruskan kepada petani. Pola transmisi harga seperti ini terjadi pada pasar monopsoni dimana pedagang dapat mengendalikan harga beli dari petani.

Shuhada et al. (2015) menyatakan bahwa dalam pemasaran produk pertanian apabila transmisi harga dari pedagang pengecer kepada petani (produsen) bernilai rendah, merupakan salah satu indikator bahwa struktur pasar yang terbentuk adalah oligopoli, dan mencerminkan adanya kekuatan monopsoni atau oligopsoni yang dilakukan pedagang pengecer. Petani yang merupakan produsen sepelaku pemasaran ditingkat paling bawah bertindak sebagai price taker (penerima harga) yang diberikan oleh pedagang pengumpul desa.

Fluktuasi harga sering terjadi pada produk pertanian yang biasanya diluar kendali petani. Harga tinggi apabila produksi rendah, sebaliknya apabila panen raya maka harga yang diterima cenderung rendah, bahkan produk bisa tidak laku terjual karena banyaknya produk yang beredar di pasar. Akibat fluktuasi harga yang tinggi dan kentang merupakan tanaman musiman serta produksinya yang fluktuatif membuat petani sering mengalami ketidakpastian pendapatan atau keuntungan yang diperoleh petani. Kusumah (2018) mengatakan bahwa ketidakstabilan (inherentinstability) pada sisi penawaran merupakan suatu fenomena yang terjadi akibat fluktuasi harga yang tinggi pada sektor pertanian. Hasil pertanian dapat disebabkan karena produk pertanian yang mudah rusak, dalam jangka pendek pada saat harga rendah tidak dapat mengurangi jumlah produksi atau menambah permintaan. Benny (2001) menjelaskan dinamika harga kentang di Indonesia. Sistem pemasaran kentang mempengaruhi tingkat transmisi harga pada tingkat pedagang besar ke harga ditingkat petani. Kohls dan Uhl (2002) menyatakan bahwa saat ini orientasi dalam kegiatan pertanian telah berubah, dari pertanian yang berorientasi kepada produksi menuju pertanian yang berorientasi pasar.

\section{SIMPULAN}

Laju perubahan harga ditingkat petani kentang lebih kecil dibandingkan dengan laju perubahan harga ditingkat pedagang pengecer, sehingga pasar kurang efisien. Transmisi harga dari konsumen ke produsen dan sebaliknya dari produsen ke konsumen kurang berjalan dengan baik. Penurunan produksi membuat dampak dari adanya harga kentang yang tidak pasti dari musim ke musim. 
DAFTAR PUSTAKA

Andriani. A., Any Suryantini., dan Masyhuri. 2017. Perilaku dan peramalan harga kentang dan toat di Kabupaten Magelang: pendekatan motedi ARIMA. Skripsi. Universitas Gadjah Mada; Yogyakarta.

Asmarantaka RW. 2012. Pemasaran Agribisnis (Agrimarketing). Departemen Agribisnis Fakultas Ekonomi dan Manajemen. IPB. Bogor.

Badan Pusat Statistik. 2018. Statistik Kabupaten Magelang dalam Angka. BPS Kabupaten Magelang.

Benny, R. 2001. Dinamika harga dan perdagangan komoditas kentang. Pusat Penelitian \& Pengembangan Sosial Ekonomi Pertanian Bogor. BadanLitbang-Departemen

Pertanian. AnalisisKebijakan Pertanian ISSN : 1693-202.

Direktorat Jenderal Hortikultura. 2018. Rencana Strategis Direktorat Jenderal Hortikultura Tahun 2018. Jakarta.

Fatimah. S. N. 2011. Analisis pemasaran kentang (Solanum tubersoum L.) di Kabupaten Magelang Skripsi. Universitas Negeri Surakarta; Surakarta.

Handayani, Basunda. P., Murti. R. H., dan Sofiari. Perubahan morfologi dan toleransi tanaman kentang terhadap suhu tinggi. J. Horti. 23 (04): 318 328.

Irawan, B. 2017. Fluktuasi harga, transmisi harga, dan marjin pemasaran sayuran dan buah. Analisis Kebijakan Pertanian. 5 (4): 358-373.
Kohls, R.L., dan Uhl, J.N. 2002. Marketing of Agricultural Product. Prentice Hall; New York.

Kusumah, A. 2018. Elastisitas transmisi harga komoditas cabai merah di Jawa Tengah. Economic Development Analysis Journal. 7 (03): 294-304.

Martin, S. 2002. Industrial Economics: Economic Analysis \& Public Policy. Second Edition. New York: Mac. Milan

Purwanto. M. J., Mohd. Harisudin., dan Aulia Qonita. 2016. Strategi pengembangan budidaya kentang (Solanum tubersoum L.) di Kabupaten Magelang. J. SEPA 13 (01): 53-62.

Pusdatin. 2018. Statistik Harga Komoditas Pertanian. Pusat Data dan Sistem Informasi Pertanian Kementrian Pertanian; Jakarta.

Rahayu. S. R. 2009. Analisis efisiensi pemasaran jagung (Zae Mays) di Kabupaten Grobogan (studi kasus di Kecamatan Geyer). Journal of Rural and Development. 2 (01): 45- 61.

Setiawan. A. F., dan Adi .H. 2014. Fluktuasi harga komoditas pangan dan dampaknya terhadap inflasi di Provinsi Banten. J. Ekonomi Pertanian, Sumberdaya, dan Lingkungan. 2 (2014): 81 - 97.

Shuhada. R., Ermi. T., dan Suardi. T. 2015. Analisis pemasaran dan transmisi harga pada petani karet pola swadaya di Desa Gobah Kecamatan Tambang Kabupaten Kampar. Jom Faperta. 2 (02): 1 14.

Walpole. 2000. Pengantar Statistik. Gramedia; Jakarta. 
